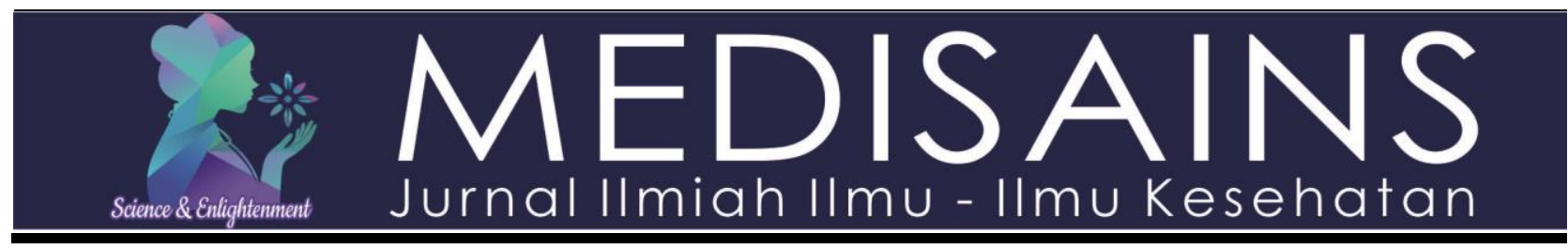

Editorial

\title{
Stunting, risk factor, effect and prevention Ragil Setiyabudi
}

Nursing Department, Health Science Faculty, Universitas Muhammadiyah Purwokerto, Purwokerto, Jawa Tengah, Indonesia

\section{A B S T R A C T}

Stunting still becomes a problem for Indonesian today. There are many risk factors which cause stunting, whether in short and long term effect. It can be overcome by a national nutrition awareness movement which involves multiple sectors which addresses to pregnant/childbirth women, toddlers, school-age children, teenagers and young adults and family empowerment.

\section{STUNTING}

Stunting is a condition when a child has low length or height compared to their age. This condition is measured by length or height below minus two standard deviations from the median standard of child growth from WHO 2005 1 . The prevalence of stunting children in the world in 2000 , $2005,2010,2015$, and 2017 were $32.6 \%, 29.3 \%, 26.1 \%$, $23.2 \%, 22.2 \%$. Despite the decline, the government put stunting as a priority problem because of its serious impact. In 2017, more than half of stunting children in the world came from Asia (55\%). Indonesia was included in the third country with the highest prevalence in the South East Asia Regional (SEAR). The average prevalence of stunting children in Indonesia in $2005-2017$ was $36.4 \%$. The incidence of stunting (short) under five is a major nutritional problem facing in Indonesia. Based on Nutritional Status Monitoring (PSG) data for 2015-2017, stunting has become the highest prevalence compared to other nutritional problems such as malnutrition, thinness and fat. The stunting prevalence of children had increased from $27.5 \%$ in 2016 to $29.6 \%$ in $2017^{2}$.

\section{RISK FACTOR}

Stunting children is considered as chronic nutritional disorder caused by various factors including history of infectious diseases, health services, immunization status, exclusive breastfeeding, zinc and iron adequacy levels, maternal height $<150 \mathrm{~cm}$, maternal age, parent education level, mother's knowledge, family income, food availability in family, food diversity, sanitation, energy intake level, duration of infectious disease history, birth weight, birth length, and genetics. From the above factors, the most dominant factors affecting stunting in children are exclusive breastfeeding and adequate nutrition during pregnancy and after child birth ${ }^{1,3-8}$.

\section{EFFECT}

The short-term effects caused by stunting are an increase in the incidence of morbidity and death, reduced cognitive, motor and verbal capacity in children, and an increase in health costs. The long-term impacts are shorter stature as an adult, increased risk of obesity and other diseases, decreased reproductive health, lack of learning capacity and school performance, reduced productivity and work capacity ${ }^{2}$. Stunting may cause pain and death, suboptimal brain development so that motor development is delayed and stunted mental growth ${ }^{6}$. The effects of stunting include lack of child growth, lack of endurance, lack of intelligence, and low productivity ${ }^{9}$. Stunting children face a greater likelihood to grow into less educated, poor, unhealthy adults and more vulnerable to non-communicable diseases ${ }^{10}$.

\section{PREVENTION}

Stunting prevention can be carried out through focusing on activities addressed to pregnant and childbirth women, children, school-age children, adolescents and young adults $^{2}$. Children are necessary to consume various kinds of vegetables and fruits ${ }^{8}$, and routine monitor of their growth in posyandu (Integrated Service Post) ${ }^{11}$. At school age, it is carried out by examining worms and all age groups must behave cleanly and healthily ${ }^{12}$. Family empowerment by cultivating the yard as a source of family 
nutrition $^{1}$, Scaling Up Nutrition (SUN) or the national nutrition awareness movement in the context of accelerating nutrition improvement in the first 1000 days of life, private and public sector collaboration in providing and accessing nutritious food can be solutions for stunting prevention ${ }^{13}$.

\section{REFERENCES}

1. Kusumawati E, Rahardjo S, Sari HP. Model of Stunting Risk Factor Control among Children under Three Years Old. Kesmas J Kesehat Masy Nas. 2015;9(3):249-256.

2. Kemenkes RI. Bulletin jendela data dan informasi kesehatan; Situasi Balita Pendek (Stunting) di Indonesia. Kementrian Kesehat RI. 2018:6-38.

3. Ramadhan R, Ramadhan N. Determinasi Penyebab Stunting Di Provinsi Aceh. SEL;Jurnal Penelit Kesehat. 2018;5(2):71-79.

4. Ni'mah K, Nadhiroh SR. Faktor Yang Berhubungan Dengan Kejadian Stunting Pada Balita. Media Gizi Indones. 2015;10(1):13-19.

5. Aridiyah FA, Ninna Rohmawati N, Ririanty M. The Factors Affecting Stunting on Toddlers in Rural and Urban Areas. e-Jurnal Pustaka Kesehat. 2015;3(1):163-170.

6. Azriful, Bujawati E, Habibi, Aeni S, Yusdarif. Determinan Kejadian Stunting Pada Balita Usia 2459 Bulan Di Kelurahan Rangas Kecamatan Banggae Kabupaten Majene. Al-Sihah Public Heal Sci J. 2018;10(2):192-203.

7. Setiawan E, Machmud R, Masrul. Faktor-Faktor yang Berhubungan dengan Kejadian Stunting pada Anak Usia 24-59 Bulan di Wilayah Kerja Puskesmas Andalas Kecamatan Padang Timur Kota Padang Tahun 2018. J Kesehat Andalas. 2018;7(2):163-170.

8. Widyaningsih NN, Kusnandar Anantanyu S. Keragaman pangan, pola asuh makan dan kejadian stunting pada balita usia $24-59$ bulan. $J$ Gizi Indones (The Indones J Nutr. 2018;7(1):22-29.

9. Nasution D, Nurdiati DS, Huriyati E. Berat badan lahir rendah (BBLR) dengan kejadian stunting pada anak usia 6-24 bulan. J Gizi Klin Indones. 2015;11(1):31-37

10. Astutik RA, Rahfiludin MZ. Faktor Risiko Kejadian Stunting Pada Anak Balita Usia 24-59 Bulan (Studi Kasus Di Wilayah Kerja Puskesmas Gabus li Kabupaten Pati Tahun 2017). J Kesehat Masy. 2018;6(1):409-418

11. Wasaraka YNK, Prawirohartono EP, Soenarto Y. Perbedaan proporsi stunting pada anak usia 12-24 bulan berdasarkan pemanfaatan pelayanan posyandu di Kabupaten Jayapura, Papua. J Gizi Klin Indones. 2015;12(02):72-78.

12. Pratama IS, Aini SR, Maharani BF. Implementasi Gasing (Gerakan Anti Stunting) Melalui PHBS Dan Pemeriksaan Cacing. J Pendidik dan Pengabdi Masy. 2019;2(1):80-83.

13. Mitra. Permasalahan Anak Pendek (Stunting) dan Intervensi untuk Mencegah Terjadinya Stunting (Suatu Kajian Kepustakaan). J Kesehat Komunitas. 2015;2(6):254-261. 